\begin{tabular}{|l|l|l||}
\hline \multicolumn{2}{|c|}{ PublisherInfo } \\
\hline \hline PublisherName & $:$ & BioMed Central \\
\hline \hline PublisherLocation & $:$ & London \\
\hline \hline PublisherImprintName & $:$ & BioMed Central \\
\hline \hline
\end{tabular}

\title{
Tyro 3 family kinases TAMper with autoimmunity
}

\begin{tabular}{||l|l|l||}
\hline \multicolumn{2}{|c||}{ ArticleInfo } \\
\hline \hline ArticleID & $:$ & 66 \\
\hline \hline ArticleDOI & $:$ & $10.1186 /$ ar-2001-70502 \\
\hline \hline ArticleCitationID & $:$ & 70502 \\
\hline \hline ArticleSequenceNumber & $:$ & 23 \\
\hline \hline ArticleCategory & $:$ & Paper Report \\
\hline \hline ArticleFirstPage & $:$ & 1 \\
\hline \hline ArticleLastPage & $:$ & 4 \\
\hline \hline & & RegistrationDate $: 2001-8-10$ \\
& $:$ & Received \\
ArticleHistory & & Accepted 2001-8-10 \\
& $:$ 2001-9-26 \\
\hline \hline ArticleCopyright & $:$ & Biomed Central Ltd2001 \\
\hline \hline ArticleGrants & $:$ & \\
\hline \hline
\end{tabular}




\begin{tabular}{|l|l|l||}
\hline ArticleContext & $:$ & 130753311 \\
\hline
\end{tabular}

Erik Peterson, ${ }^{\text {Aff1 }}$

Aff1 University of Pennsylvania, PA, USA

\section{Keywords}

Autoimmunity, knockout mice, receptor protein tyrosine kinases

\section{Context}

Controlling the number of lymphocytes and their activation status are keys in the prevention of autoimmunity. Known molecular factors that contribute to prevention of autoimmune phenomena include antigen-presenting cell (APC)-T-cell interactions (stimulating activation induced apoptosis), as well as an array of death receptors and inhibitory molecules. Until very recently, receptor protein tyrosine kinases (rPTKs)-cell surface enzymes capable of engaging cytoplasmic signaling cascades-were not found on lists of proteins playing immune regulatory roles. Tyro 3, Axl, and Mer are closely related rPTKs that make up the Tyro 3 family. They are widely expressed, but importantly, are not found in B or T lymphocytes. Previous work implicated these receptors in spermatogonial and neural development (see Additional information [1]), as well as in clearance of apoptotic cells (see Additional information [2]). The aim of the current study was to characterize the immune cell phenotype of animals made triply deficient in Tyro 3, Axl, and Mer.

\section{Significant findings}

Tyro 3-, Axl-, and Mer-deficient $\left(\mathrm{TAM}^{-/}\right)$animals exhibit a number of classic autoimmune features. Their massively enlarged spleens and lymph nodes contain expanded numbers of inappropriately activated $\mathrm{B}$ cells and $\mathrm{T}$ cells. Additionally, nonlymphoid tissues from $\mathrm{TAM}^{-/-}$mice contain focal collections of lymphocytes. The $\mathrm{TAM}^{-/}$mice have arthritis and elevated titers of anti-dsDNA and antiphospholipid autoantibodies.

Autoimmunity in the $\mathrm{TAM}^{-/-}$mice is attributable to primary myeloid, rather than lymphoid hyperactivity. Tyro 3, Axl, or Mer transcripts are present exclusively in myeloid-enriched, nonlymphoid areas of the spleen (red pulp and marginal zones) and thymus (central medulla). Further, resting wild- 
type lymphocytes proliferate spontaneously when transferred into $\mathrm{TAM}^{-/}$, but not wild-type hosts. Finally, splenic $\mathrm{TAM}^{-/-}$macrophages have an activated surface phenotype, hypersecrete IL-12, and show enhanced phagocytosis and responses to lipopolysaccharides in vitro.

\section{Comments}

Strikingly, anti-dsDNA and antiphospholipid antibodies in the $\mathrm{TAM}^{-/-}$mice correlate with the presence of pregnancy losses and cerebral hemorrhages, prompting comparison of the phenotype with the human antiphospholipid antibody syndrome. The findings support the notion that lymphoid hyperactivation in $\mathrm{TAM}^{-/-}$mice is not a primary defect. Rather, loss of Tyro 3, Axl, and Mer causes APC hyperactivity, with secondary lymphoid activation.

The $\mathrm{TAM}^{-/-}$mice establish a novel immune-inhibitory signaling axis, and highlight the importance of suppressing APC activation in the containment of autoimmunity. Future pathogenetic investigations into disease states such as systemic lupus and the antiphospholipid antibody syndrome may reveal abnormalities in the signaling events dependent upon these rPTKs.

\section{Methods}

Gene targeting, flow cytometry, adoptive transfer, histochemistry

\section{Additional information}

1. Lu Q, Gore M, Zhang Q, Camenisch T, Boast S, Casagranda F, Lai C, Skinner MK, Klein R, Matsushima GK, Earp HS, Goff SP, Lemke G: Tyro-3 family receptors are essential regulators of mammalian spermatogenesis. Nature 1999, 398:723-728 (PubMed abstract).

2. Scott RS, McMahon EJ, Pop SM, Reap EA, Caricchio R, Cohen PL, Earp HS, Matsushima GK: Phagocytosis and clearance of apoptotic cells is mediated by MER. Nature 2001, 411:207-211 (PubMed abstract). 


\section{References}

1. Lu Q, Lemke G: Homeostatic regulation of the immune system by receptor tyrosine kinases of the tyro 3 family. Science. 2001, 293: 306-311.

This PDF file was created after publication. 